\title{
Development of Pop-Up Book Media Based on Balanced Literacy Approach to Improve Skills of Reading Class 1 Students Basic School
}

\author{
Novi Wulandari; Hendratno; Titik Indarti \\ Surabaya State University, Indonesia \\ http://dx.doi.org/10.18415/ijmmu.v7i5.1726
}

\begin{abstract}
The background that drives this research is the low interest in reading and the lack of reading skills in grade 1 students. The purpose of this study is to produce a pop-up book based on a good quality balanced literacy approach. The test subjects in this study were 60 first grade students at SDN Pacarkeling V / 186 Surabaya. The method used in this study is the method of developing Research and Development (R\&D). The development model of Borg and Gall in this study goes through 10 stages. The product developed in this research is a valid, practical and effective pop-up book media. The validation results show that the developed media is valid with very good criteria. Practicality in small scale and large scale trials reaches very good category. The effectiveness of the developed media can be seen from the increase in the results of the reading skills test using the $t$ test with the t-test result of -11.6.
\end{abstract}

Keywords: Balanced Literacy; Development; Media Pop-Up Books; Reading Skills

\section{Introduction}

The low reading ability at the first grade students of SDN Pacarkeling V / 186 Surabaya needs to be a concern for teachers. Considering reading skills are the main activities of first grade students that must be carried out or delivered because reading is the beginning of one of the basic skills in learning advanced reading skills. It has correlation with students' ability in responding the materials given by the students (Anggraini, Murwaningsih, \& Winarni, 2018). In language mastery, reading is very essential (Dinarty, 2019). Reading skills need to be possessed by elementary students. Beginning reading is learning to read in elementary school conducted by students in grades I and II. Barriers to difficulties in beginning reading skills can be done by doing an interesting and fun teaching and learning process and fostering interest in reading in children through the use of media that can attract students' interests. According to Rahmawati (2018, p. 2) learning media has an important role to increase the effectiveness of teaching and learning activities, increase the experience of students in learning, can increase student attention, make students more eager to learn according to the material to be studied, allowing the use of the five senses, minimize differences in perceptions between teachers and students, add positive contributions from students in gaining learning experiences, help solve personal differences between students, and be more economical. Grade 1 students in elementary schools are more interested in book 
media that have three-dimensional images. Pop-up book media is one of the three-dimensional drawing media that is packaged in a book and is suitable if given to low grade students.

Pop-up books or mobile books are three-dimensional books that contain pieces of paper that can move or appear when the book is fully opened and folded when the book is closed (Ahmadi, Fakhruddin, Trimurti, \& Khasanah, 2017, p. 34). According to Fadilah, Royana, \& Handayani (2019, p. 224) a pop-up book is a book in which there are folds of pieces in the form of three-dimensional layers and are also capable of being moved so that the reader does not feel saturated. Furthermore, Sinegar \& Rahmah (2016, p. 12) explained that the Pop-up book is a book whose parts can be moved and have three-dimensional elements. Based on the opinion above, it can be interpreted that the Pop-up book is a book in which every page in it contains movable parts and has three-dimensional elements.

According to Indartono (2016, p. 11) the benefit of a Pop-up book is that a pop-up book is able to display real objects that are realized in three-dimensional images so that it is easier for children to know objects and the teacher will be easier to provide material to be taught and pop-ups. book has an element of surprise when the page that is opened contains images that are able to move so that it can increase the enthusiasm of students in participating in learning activities and can increase student interest in learning.

In this research, the developed Pop-up book media will be used as a medium for first grade students in elementary schools with the aim of improving students' reading abilities. Teaching and learning process will become a learning activity that is more interesting, interactive, and effective. The process of learning activities in this study uses a balanced literacy approach. Yuliati (2016, p. 118) defines balanced literacy as an integrated design approach to the balance of reading and writing through several components of hard reading, guided reading, independent reading, joint writing, interactive writing, and independent writing. The balance literacy approach and information literacy movement are believed to be able to foster students' reading and writing culture. The experts acknowledge the students' literacy culture successfully developed using the theory of the balance literacy approach.

The balance literacy approach balances skills, and meaning-based instruction to ensure student reading and writing results (Bingham and Kenyon, 2013, p. 16). According to Siaulys (2013, p. 9) the system of balanced literacy includes all matters relating to literacy, phonetics, spelling, writing, reading, and all oral communication must be included as part of a balanced curriculum. Balanced literacy provides opportunities for experience in reading and writing through learning that balances students' literacy skills (Yuliati, 2014, p. 118). The balanced literacy approach is useful in developing students' literacy skills because balanced literacy is a design of activities aimed at helping all students to learn to read and write effectively (Hebzynski, 2017, p. 14). Basic concepts in this program are students able to learn to read and write. Reading and writing activities in a balanced way provide opportunities for students to be achieved in learning. In this activity students will receive lessons according to their abilities and adjust material that is difficult to facilitate their learning.

The balanced literacy approach is one of the right approaches to overcome the problem of students' literacy in the early grades. This is because students have different abilities from one another so that different treatments are needed. Supartinah $(2018$, p. 15) said that to realize a balanced approach in literacy learning requires integration of components which include reading, phonics, literacy skills, reading and writing strategies, vocabulary, comprehension, literature, learning content, oral language, writing, and spelling. For the learning objectives of literacy to be achieved, the components must be well integrated.

\section{Research Methods}

The research conducted is a type of development research known as Research and Development (R\&D). Research and development or (Research \& Development) has the aim to improve the effectiveness of a product design so that it is faster, easier and of quality in helping work (Sugiyono, 
2016, p. 26). This research is a development research that produces a product in the form of instructional media, which is a pop-up book based on balanced literacy on the theme "myself" subtema "my body" class I Elementary School.

The concept in this research development can be interpreted as an effort to develop through various stages and development procedures accompanied by validation efforts through effectiveness testing. The Borg and Gall development model (in Sukmadinata, 2013, p. 169-170) in this study went through 10 stages including: (1) research and data collection, (2) planning stage, (3) design phase, (4)) initial field trials, (5) Revision of product development trial results, (6) Field trials (large scale), (7) Improvement of field test product results, (8) Field implementation test stages, (9) Improvement of final product, (10) Dissemination.

The subjects used in this study were first grade students at SDN Pacarkeling V / 186 Surabaya. Data analysis techniques developed in this research are using qualitative data analysis and quantitative data analysis. Qualitative data analysis in the form of comments and suggestions for improvement from the validator. Quantitative data in the form of assessment scores from various instruments of product validation data analysis obtained from the validation and revision stages; instruments for analyzing student observation data, analyzing questionnaires for teachers and students conducted during the smallscale field trial phase; and analysis instruments for reading skills tests during the small and large scale field trial phase as well as analysis as the final product.

Pop-up book media based on the balanced literacy approach in this study is declared valid if the scores obtained are categorized as good with a percentage in the range of numbers between $75 \%-84 \%$, the minimum percentage that must be obtained in each aspect (material / content, linguistic, and graphic) namely in the range of $60 \%-74 \%$. If one of the three aspects does not meet the minimum criteria, then the pop-up book media based on the balanced literacy approach is declared not quality.

The practicality of pop-up book media is obtained from observations of teacher and student activities during learning and the results of teacher and student responses. If all four aspects show good or very good categories, then the pop-up book media has practical or very practical categories in learning. The effectiveness of pop-up book media is determined based on student learning outcomes. Mastery learning outcomes individually with a minimum value of 70 then calculate the completeness in a classical manner where students are declared to be classically complete> $80 \%$.

In analyzing the impact of the use of the developed media product, it uses a one-group pretestposttest design experimental design. Before the treatment is given a pretest first on this design. The treatment can be known the results are more accurate because it can compare with conditions before being given treatment. There is no control class in this design. To measure the improvement of initial reading skills by using a pop-up book media based on the balanced literacy approach, the two sample interrelated t-test data analysis techniques were used.

\section{Research Results and Discussion}

The process of developing a pop-up book media based on a balanced literacy approach uses the Borg and Gall model which is carried out through 10 stages: (1) research and data collection which includes gathering initial data and information, data in the form of literature review and classroom observation activities. (2) the planning stage which consists of four steps of activities namely analyzing the Task, analyzing the Concept, analyzing the Formulation of Learning Objectives, and making a research instrument lattice that becomes the evaluation criteria of the pop-up book media based on the balanced literacy approach. (3) design phase by making pop-up book media products based on the balanced literacy approach, at this stage the validator will validate draft media I. (4) initial field trials of media application are carried out to test the effectiveness of Draft I media before being tested in first 
grade students of SDN Pacarkeling V / 186. (5) The revision of the product development trial results is carried out after validation as well as the initial (small scale) field trials. Draft I. (6) Field trials (large scale) on the application of the Draft II media using experimental designs. (7) Improvement of the product of field test results, at this stage no improvement is made of the pop-up book media product based on the balanced literacy approach because the media used are already very valid. (8) The stage of the field implementation test was not carried out because the media made were already feasible and practically used in learning pop-up book media based on the balanced literacy approach which was very practical to be used in learning. (9) Completion of the final product is made of products made from large-scale field test results. (10) Dissemination is done by distributing to class I teachers throughout the Tambaksari District of Surabaya City who are members of the KKG (Teacher Working Group).

The validity of media development products is based on the results of the validation of the material expert validator and the media expert validator. The validity of product development is based on three aspects, namely the validity of the material, the validity of the graphics, and the validity of the language. The validity of the material and language is based on the judgment of the material expert validator and the validity of the graphic is based on the judgment of the media expert. Evaluation of development product validation was carried out twice, namely Draft I and Draft II. The criteria for evaluating pop-up book media based on the balanced literacy approach are explained in the following table 1:

\section{Table 1 Criteria for evaluating the validity of Pop-up Book media based on the Balanced Literacy Approach}

\begin{tabular}{|c|c|}
\hline Scoring Grade & Chriteria \\
\hline $85 \%-100 \%$ & Sangat baik \\
\hline $75 \%-84 \%$ & Baik \\
\hline $60 \%-74 \%$ & Cukup \\
\hline $40 \%-59 \%$ & Kurang \\
\hline $0 \%-39 \%$ & Sangat kurang \\
\hline
\end{tabular}

The results of the validation of every aspect of the pop-up book media based on the balanced literacy approach that has been carried out by the validator are explained in table 2 below:

Table 2. The results of the pop-up book media validation based on the balanced literacy approach

\begin{tabular}{|c|l|c|c|}
\hline No & \multicolumn{1}{|c|}{ Aspect } & Draft I & $\begin{array}{c}\text { Draft } \\
\text { II }\end{array}$ \\
\hline 1 & Materi/isi & $81,6 \%$ & $96,6 \%$ \\
\hline 2 & Kebahasaan & $81,25 \%$ & $93,7 \%$ \\
\hline 3 & Kegrafikan & $83,3 \%$ & $93,75 \%$ \\
\hline
\end{tabular}

Media development products (Draft II) each aspect obtains an optimal validation value and is declared valid without revision. The researcher ended the development process and became Draft II as the final product of pop-up book media based on the balanced literacy approach. The final media development product contains relevant material because it has received a valid status from the validator. This valid media is in the form of books and is valid according to the media validator.

The practicality of using pop-up book media development products based on the balanced literacy approach is obtained from observing teacher activities, observing student activities, teacher and student response data on research instrument sheets. The results of the observation activities of teachers and students are then transformed into the following categories: 
Table 3. Observation Category Teacher Activity

\begin{tabular}{|l|l|}
\hline \multicolumn{1}{|c|}{ Score } & Teacher Activities Category \\
\hline $81 \%-100 \%$ & Done very well and effectively \\
\hline $61 \%-80 \%$ & Done well and effective \\
\hline $41 \%-60 \%$ & Effective enough to be implemented \\
\hline $21 \%-40 \%$ & Not working and ineffective \\
\hline $0 \%-39 \%$ & Less working and less effective \\
\hline
\end{tabular}

Table 4. Categories of Student Activity Observation

\begin{tabular}{|c|l|}
\hline Score & Student Activities Category \\
\hline $81 \%-100 \%$ & Very active in the instructional \\
\hline $61 \%-80 \%$ & Active in the instructional \\
\hline $41 \%-60 \%$ & $\begin{array}{l}\text { Active enough in the } \\
\text { instructional }\end{array}$ \\
\hline $21 \%-40 \%$ & Less active in the instructional \\
\hline $0 \%-39 \%$ & Passive in the instructional \\
\hline
\end{tabular}

The results of teacher and student responses are then transformed into student response criteria. If the percentage of positive student responses in each component is obtained $>56 \%$ then it can be said to be a positive student response. The criteria for student and teacher response categories are explained in the following table 5:

Table 5. Teacher and Student Response Categories

\begin{tabular}{|c|c|}
\hline Score & $\begin{array}{c}\text { Response } \\
\text { Category }\end{array}$ \\
\hline $86 \%-100 \%$ & Sangat baik \\
\hline $71 \%-85 \%$ & Baik \\
\hline $56 \%-70 \%$ & Cukup \\
\hline $41 \%-55 \%$ & Kurang \\
\hline $25 \%-40 \%$ & Sangat kurang \\
\hline
\end{tabular}

The results of observations of teacher activities, student activities, teacher responses and student responses to small-scale trial activities (Draft I) and large-scale trials (Draft II) are as follows:

Table 6. Results Observation of teacher activity, student activity, teacher response, and student response

\begin{tabular}{|l|c|c|}
\hline \multicolumn{1}{|c|}{ Aspect } & Draf I & Draf II \\
\hline Teacher activities & $84.5 \%$ & $94.7 \%$ \\
\hline Student activities & $83.5 \%$ & $92.7 \%$ \\
\hline Teacher respond & $84.7 \%$ & $94.4 \%$ \\
\hline Sudent respond & $92.5 \%$ & $92.9 \%$ \\
\hline \multicolumn{1}{|c|}{ Aspect } & Draf I & Draf II \\
\hline Teacher activities & $84.5 \%$ & $94.7 \%$ \\
\hline Student activities & $83.5 \%$ & $92.7 \%$ \\
\hline Teacher respond & $84.7 \%$ & $94.4 \%$ \\
\hline Sudent respond & $92.5 \%$ & $92.9 \%$ \\
\hline
\end{tabular}

Based on data from observations of teacher activities, observations of student activities, teacher responses, and student responses, it was concluded that the media for learning pop-up books based on the balanced literacy approach is very practical to be used in learning. 
The quality of media development products is also seen from the aspect of effectiveness. The effectiveness of the intended media is that the media developed can improve the reading skills of grade 1 students. Students' reading skills are measured from the reading skills produced by reading a reading. Trial application of the product using an experimental design. The experimental design used is the one group pretest posttest design, in which there is no control class. In this design students are given a pretest before being given treatment. After being treated in the form of the application of pop-up book media based on a balanced literacy approach, students are given a posttest. The results of the reading skills test between the pretest and posttest were then compared with the t-test. The results of students' reading skills tests are outlined in the following table

Table 7. Data Reading Test Results for Class I Students

\begin{tabular}{|c|c|c|c|}
\hline No & $\begin{array}{l}\text { Students } \\
\text { Name }\end{array}$ & $\begin{array}{c}\text { Score } \\
\text { (Pretest) }\end{array}$ & Score (Posttes) \\
\hline 1 & Student 1 & 85 & 95 \\
\hline 2 & Student 2 & 50 & 95 \\
\hline 3 & Student 3 & 55 & 95 \\
\hline 4 & Student 4 & 65 & 90 \\
\hline 5 & Student 5 & 90 & 90 \\
\hline 6 & Student 6 & 90 & 100 \\
\hline 7 & Student 7 & 85 & 90 \\
\hline 8 & Student 8 & 50 & 90 \\
\hline 9 & Student 9 & 85 & 100 \\
\hline 10 & Student 10 & 85 & 85 \\
\hline 11 & Student 11 & 60 & 90 \\
\hline 12 & Student 12 & 80 & 85 \\
\hline 13 & Student 13 & 85 & 100 \\
\hline 14 & Student 14 & 85 & 95 \\
\hline 15 & Student 15 & 80 & 75 \\
\hline 16 & Student 16 & 55 & 90 \\
\hline 17 & Student 17 & 60 & 90 \\
\hline 18 & Student 18 & 60 & 95 \\
\hline 19 & Student 19 & 90 & 95 \\
\hline 20 & Student 20 & 60 & 90 \\
\hline 21 & Student 21 & 85 & 90 \\
\hline 22 & Student 22 & 85 & 90 \\
\hline 23 & Student 23 & 85 & 85 \\
\hline 24 & Student 24 & 60 & 80 \\
\hline 25 & Student 25 & 75 & 95 \\
\hline 26 & Student 26 & 60 & 100 \\
\hline 27 & Student 27 & 55 & 95 \\
\hline 28 & Student 28 & 55 & 85 \\
\hline 29 & Student 29 & 60 & 95 \\
\hline 30 & Student 30 & 80 & 85 \\
\hline 31 & Student 31 & 50 & 95 \\
\hline 32 & Student 32 & 60 & 80 \\
\hline 33 & Student 33 & 55 & 100 \\
\hline 34 & Student 34 & 80 & 95 \\
\hline 35 & Student 35 & 85 & 85 \\
\hline 36 & Student 36 & 80 & 80 \\
\hline 37 & Student 37 & 35 & 65 \\
\hline
\end{tabular}




\begin{tabular}{cccc}
\hline 38 & Student 38 & 55 & 90 \\
\hline 39 & Student 39 & 50 & 85 \\
\hline 40 & Student 40 & 85 & 90 \\
\hline 41 & Student 41 & 80 & 85 \\
\hline 42 & Student 42 & 55 & 85 \\
\hline 43 & Student 43 & 85 & 95 \\
\hline 44 & Student 44 & 50 & 90 \\
\hline 45 & Student 45 & 55 & 85 \\
\hline 46 & Student 46 & 60 & 65 \\
\hline 47 & Student 47 & 55 & 80 \\
\hline 48 & Student 48 & 80 & 95 \\
\hline 49 & Student 49 & 80 & 90 \\
\hline 50 & Student 50 & 80 & 90 \\
\hline 51 & Student 51 & 60 & 90 \\
\hline 52 & Student 52 & 50 & 90 \\
\hline 53 & Student 53 & 80 & 95 \\
\hline 54 & Student 54 & 55 & 95 \\
\hline 55 & Student 55 & 60 & 90 \\
\hline 56 & Student 56 & 50 & 65 \\
\hline 57 & Student 57 & 60 & 95 \\
\hline 58 & Student 58 & 60 & 95 \\
\hline 59 & Student 59 & 75 & 90 \\
\hline 60 & Student 60 & 60 & 75 \\
\hline Classical average & 68 & 89 \\
\hline Average & Succeed & $45 \%$ & $95 \%$ \\
Students Percentage & Failed & $55 \%$ & $5 \%$ \\
\hline Average & Students Percentage & & \\
\hline
\end{tabular}

The level of effectiveness of the media, measured by comparing student learning outcomes before and after using media learning to write based on visual literacy. The results of the pretest and posttest were compared with the technical analysis of the two small sample tests which were interconnected. The steps determine the value of the $t$ test as follows.

a. Determine the Standard Deviation from the difference in the pretest and posttest values

$$
\begin{gathered}
\mathrm{SD}_{\mathrm{D}}=\sqrt{\frac{\sum \mathrm{D}^{2}}{\mathrm{~N}}-\left(\frac{\sum \mathrm{D}}{\mathrm{N}}\right)^{2}} \\
\mathrm{SD}_{\mathrm{D}}=\sqrt{\frac{39.050}{60}-\left(\frac{-1260}{60}\right)^{2}} \\
\mathrm{SD}_{\mathrm{D}}=\sqrt{\frac{39.050}{60}-(-21)^{2}} \\
\mathrm{SD}_{\mathrm{D}}=\sqrt{650,83-441} \\
\mathrm{SD}_{\mathrm{D}}=\sqrt{209,833} \\
\mathrm{SD}_{\mathrm{D}}=14,485
\end{gathered}
$$


b. Determine the Standard Error of the Mean of Difference $\left(M_{D}\right)$

$$
\begin{aligned}
\mathrm{SE}_{\mathrm{M}_{\mathrm{D}}} & =\frac{\mathrm{SD}_{\mathrm{D}}}{\sqrt{\mathrm{N}-1}} \\
\mathrm{SE}_{\mathrm{M}_{\mathrm{D}}} & =\frac{14,485}{\sqrt{59}} \\
\mathrm{SE}_{\mathrm{M}_{\mathrm{D}}=1,8} & \mathrm{SE}_{\mathrm{M}_{\mathrm{D}}}=\frac{14,485}{7,681}
\end{aligned}
$$

c. Determine the value of $M_{D}$

d. Determine the calculated t value (to)

$$
\begin{gathered}
\mathrm{M}_{\mathrm{D}}=\frac{\sum \mathrm{D}}{\mathrm{N}} \\
\mathrm{M}_{\mathrm{D}}=\frac{-1260}{60}=-21
\end{gathered}
$$

$$
\begin{aligned}
& \mathrm{t}_{\mathrm{o}}=\frac{\mathrm{M}_{\mathrm{d}}}{\mathrm{SE}_{\mathrm{M}_{\mathrm{D}}}} \\
& \mathrm{t}_{\mathrm{o}}=\frac{-21}{1,8}=-11.6
\end{aligned}
$$

Seeing the results of $t$ count of -11.6 then compared with the value of $t$ table with df of 59 at a significance level of 5\%. The value of t table with df 59 at a significance level of $5 \%$ is 2.001 . Because of the $-t$ count <-t table $(-11.6<-2,001)$, the alternative hypothesis (Ha) is accepted and the null hypothesis (Ho) is rejected. There are differences in the results of students' reading skills between before and after using pop-up book media based on the balanced literacy approach.

\section{Conclusion}

Based on the research objectives and the results of the research that has been done, it can be concluded that based on research from the validator of the pop-up book media based on the balanced literacy approach, it is declared valid and is suitable for use in teaching and learning activities. The practicality of pop-up book media based on the balanced literacy approach has a very practical category both when viewed from observations of teacher and student activities as well as student and teacher responses. Posttest results regarding reading skills on the use of pop-up book media based on the balanced literacy approach were declared very effective. This is in accordance with the results of data analysis of the reading skills test experienced an increase.

\section{References}

Anggraini, C. C. D., Murwaningsih, T., \& Winarni, R. (2018). Development of materials are based on character values to improve intensive reading skill students for class III in elementary school. International Journal of Multicultural and Multireligious Understanding, 5(2), 118-127.

Dinarty, A. (2019). The use of pocket dictionary and online word-for-word translation on reading skill: an experimental study at SMAN 4 Kota Bima academic year 2018/2019. International Journal of Multicultural and Multireligious Understanding, 6(2), 135=- 144. 
Rahmawati, Sri, Rahman, Sopandi, Wahyu, \& Darmawati, Besse. (2018). Pop-up book in reading comprehension ability context in thematic learning. Jurnal Universitas Pendidikan Indonesia.

Ahmadi, F., Fakhruddin, T. M., Khasanah, K. (2017). The development of pop-up book media to improve 4th grade students' learning outcomes of civic education. Jurnal Fakultas Pendidikan Universitas Negeri Semarang Volume 4 halaman 1.

Fadzilah, F., Royana, I. F., \& Handayani, D. E. (2019). Pengembangan media pop-up book pada pembelajaran tema VI cita-citaku Subtema 1 Aku dan Cita-citaku. Jurnal Undiksha. Volume 3 (3) halaman 223-230.

Siregar, A., \& Rahmah, E. (2016). Model pop-up book keluarga untuk mempercepat kemampuan membaca anak kelas rendah sekolah dasar. Jurnal Fakultas Bahasa dan Seni Universitas Negeri Padang.

Indartono, A. R. (2016). Makalah komprehensif pengembangan media pop-up book untuk meningkatkan kemampuan membaca dan menulis pemahaman Student tunagrahita ringan Kelas V di SDLB. Surabaya: UNESA.

Yuliyati. (2014). Model budaya Bbaca-tulis berbasis balance literacy dan gerakan informasi literasi dasar di kelas awal. Jurnal Universitas Negeri Yogyakarta. Volume 11 nomor 1 halaman 1.

Bingham, G. E., \& Halt-Kenyon, K. M. (2013). Examining teachers' beliefs about and implementation of a balanced literacy framework. Jurnal Departement of Early Childhood Education, Georgia State University, USA. DOI: 10.1111/j.1467-9817.2010.01483.x.

Siaulys, K. (2013). A balanced literacy approach to the classroom. A Senior Thesis submitted in partial fulfillment of the requirement for graduation in the Honors Program Liberty University.

Hebzynski, S. J. (2017). Balanced literacy strategies. Submitted to the Graduate Faculty of St. Cloud State University in Partial Fulfillment of the Requirements for the Degree Master of Science in Curriculum and Instruction.

Supartinah, Sumardi, \& Ardi, B. S. (2018). Model pembelajaran berbasis balanced literacy approach bermuatan nilai-nilai karakter untuk pembelajaran literasi dasar di kelas awal. Jurnal Universitas Negeri Yogyakarta. Volume 11 nomor 1 halaman 11-22 /2017/.

Sugiyono. (2016). Metode penelitian kuantitatif, kualitatif, dan R\&D. Bandung: Alfabeta.

Sukamadinata, N. S. (2013). Metode penelitian pendidikan. Bandung: PT. Remaja Rosdakarya.

\section{Copyrights}

Copyright for this article is retained by the author(s), with first publication rights granted to the journal.

This is an open-access article distributed under the terms and conditions of the Creative Commons Attribution license (http://creativecommons.org/licenses/by/4.0/). 